\title{
The psychiatric hospital worker in Wonderland
}

\author{
O trabalhador do hospital psiquiátrico no País das Maravilhas \\ El trabajador en el hospital psiquiátrico en el País de las maravillas
}

Francilene Figueirêdo da Silva Pascoal' ORCID: 0000-0002-6220-0759

Alana Vieira Lordão" ORCID: 0000-0003-1941-6084

Jaqueline Brito Vidal Batista" ORCID: 0000-0002-8107-9763

'Universidade Federal de Campina Grande. Cuité, Paraíba, Brazil. "Universidade Federal da Paraíba. João Pessoa, Paraíba, Brazil.

How to cite this article: Pascoal FFS, Lordão AV, Batista JBV. The psychiatric hospital worker in Wonderland.

Rev Bras Enferm. 2021;74(Suppl 3):e20200342. doi: http://dx.doi.org/10.1590/0034-7167-2020-0342

\section{Corresponding author: Alana Vieira Lordão E-mail: alanavieirap@gmail.com}

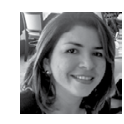

EDITOR IN CHIEF: Antonio José de Almeida Filho ASSOCIATE EDITOR: Hugo Fernandes

Submission: 07-07-2020

Approval: 09-29-2020

\section{ABSTRACT}

Objective:To propose a reflection on the labor practice in a psychiatric hospital, emphasizing Brazil. Method: A theoretical-reflexive study with an analogy between work in a psychiatric hospital and the literary work "Alice in Wonderland." Results: The complex movement of the psychiatric hospital's history induces a discordant work process and demands from the worker a personified performance of a world of "wonders." Final considerations: This manuscript contributed to the equalization of knowledge about the work in the psychiatric hospital, aiming to minimize the conceptual distortions identified and expose the worker's real situation in these institutions.

Descriptors: Mental Health; Working Conditions; Job-related Health; Psychiatric Hospitals; Knowledge.

\section{RESUMO}

Objetivo: Propor uma reflexão sobre a prática laboral em hospital psiquiátrico, com ênfase no Brasil. Método: Estudo teórico-reflexivo com analogia entre o trabalho em uma instituição hospitalar psiquiátrica e a obra literária "Alice no País das Maravilhas". Resultados: O movimento complexo da história do hospital psiquiátrico induz um processo laboral destoante e exige do trabalhador uma atuação personificada de um mundo de "maravilhas". Considerações finais: Este manuscrito contribuiu para a equalização do conhecimento acerca do trabalho no hospital psiquiátrico, visando minimizar as distorções conceituais identificadas e expor a real situação do trabalhador dessas instituições.

Descritores: Saúde Mental; Condições de Trabalho; Saúde do Trabalhador; Hospitais Psiquiátrico; Conhecimento.

\section{RESUMEN}

Objetivo: Proponer una reflexión sobre la práctica laboral en hospital psiquiátrico, con énfasis en Brasil. Método: Estudio teórico-reflexivo con analogía entre el trabajo en una institución hospitalaria psiquiátrica y la obra literaria "Alicia en el País de las Maravillas". Resultados: El movimiento complejo de la historia del hospital psiquiátrico induce un proceso laboral desviado y exige del trabajador una actuación personificada de un mundo de "maravillas". Consideraciones finales: Este manuscrito contribuyó para la ecualización del conocimiento acerca del trabajo en el hospital psiquiátrico, objetivando minimizar las distorsiones conceptuales identificadas y exponer la real situación del trabajador de esas instituciones. Descriptores: Salud Mental; Condiciones de Trabajo; Salud del Trabajador; Hospitales Psiquiátricos; Conocimiento. 


\section{INTRODUCTION}

The psychiatric hospital, created at the end of the 13th century, has always been focused on discussions about mental health care: sometimes exposed as an abomination for treating people with mental disorders, sometimes it is defended as necessary for the restoration of their health. In the middle of this dispute of values, one finds the worker responsible for the care in the psychiatric service ${ }^{(1)}$.

The interface between reality and imaginary experienced by workers in psychiatric hospitals reminded the authors of this article of the literary oeuvre "The Adventures of Alice in Wonderland," by Lewis Carrol. The book tells Alice's story when falling into a rabbit hole, transports herself to a world full of peculiar characters, who face the fear, coercion, and threats of a hierarchical structure of power, exercised by a Queen ${ }^{(2)}$. Like Wonderland, the psychiatric hospital worker faces absurd and disconcerting situations, driven by a political logic not always consistent with reality ${ }^{(3)}$.

Therefore, this study offers an analogy between the story of "Alice in Wonderland" by Lewis Carrol and the psychiatric hospital service job. Through metaphorical language, there is discussed the behavior and attitudes of workers in the context of this service, highlighting the significant theoretical, political, and structural transformations.

\section{OBJECTIVE}

To outline, in a ludic way, relevant aspects of the professional practice of psychiatric institutions, as a particular history of nosocomial organizations, often overlooked by scientific discussions.

\section{RESULTS}

\section{Psychiatric Hospital and Alice in Wonderland: The Caterpil- lar, the Queen, and the Mushroom}

Carrol's book, "The Adventures of Alice in Wonderland," and the psychiatric hospital's historical context are analogous, especially about the search for a balance between madness and reason. In the psychiatric hospital and Wonderland, the story takes place surrounded by conflicts of power. The insider is often seen as alienated, and the outsider is free to interpret a meaningless world ${ }^{(1)}$.

In the 18th century, madness had one of the most emblematic concepts, attributed to the opposite of reason, and the crazy person was called "alienated" (1). The term "alienated" identified someone outside their usual environment, reality, and self without controlling their wills and desires ${ }^{(1)}$. To elucidate this conception here follows an excerpt from the literary work of "Wonderland," presenting Alice in the context of an alienated being:

Alice, seeing herself in the world of Wonders, suffering frequent size changes (stretching and shrinking), felt lost. At a certain point, when she realized that she was not in control of the situation, she cried so much forming a pool of tears. Shortly after, she finds a Caterpillar sitting on a mushroom, who asks her, "Who are you? Alice replies: "I... I hardly know, Sir, just at present. At least I know who I was when I got up this morning, but I think I must have changed several times since then." ${ }^{\prime(2)}$.
The alienation and depersonalization characterized by Alice's speech are also identified in psychiatric hospitals' history. At first, such concepts emerged in the ideas of the French physician Philippe Pinel when he considered madness as a phenomenon of mental alienation and established the use of moral treatment in 18th-century hospitals. This treatment consisted of principles and measures imposed on the alienated to re-educate the mind and restore reason. Among some measures, it stands out the use of straitjacket, replacing the chains used during agitation and violence ${ }^{(1)}$. Pinel gained prominence in psychiatry history by being the first person to recognize madness people as patients in need of treatment. One dares say that, by that time, Pinel was considered the hero of a world in which people were exhausted from suffering ${ }^{(4)}$.

In the beginning, the practices of moral treatment (showers, cold baths, whips, and bleeds), as well as the use of electroshock and psychosurgery - used in psychiatric hospitals, known as "asylums" in the 19th century, based on organic theory - were conceived as therapeutic measures. However, studies indicate their use also as a punitive action ${ }^{(1,4)}$. The reasons for the punishment were often as eloquent as the reasons for beheading ordered by the Queen of Wonderland:

At a certain point in the story, Alice appears in the Queen's garden. Here she meets three gardeners whose bodies were shaped like playing cards. The gardeners, seeing the King and the Queen, threw themselves face down on the ground. The Queen questions the girl about their identity, but she didn't know what to answer. Angry at not getting an answer from the girl, she orders her soldiers: "Cut off her head! Cut it off...." Fortunately, the King convinces her to give up ${ }^{(2)}$.

Both in Alice's story and that of the psychiatric hospitals, their characters have suffered abuses of repressive practices. The appearances of kings in Alice's story refer to the world of fantasies, hierarchies, and rules, which, although appearing incoherent - legally and organizationally - must be followed.

Throughout the 19th and 20th centuries, in parallel with the development of the capitalist mode of production, the psychiatric hospital institutions were consolidated as the primary place to treat madness. However, they resembled more Nazi prisons and concentration camps than places reserved for treating the mentally ill. At that time, the economic interest added to the neglect of the person's dignity was so evident that it was common to have overcrowding of inmates per institution. As an example, stands out the Juquery Asylum Colony, located in São Paulo, Brazil, with 16 thousand interns ${ }^{(1,4)}$.

After the Second World War, the psychiatric institution became the target of intense criticism from personalities from different countries: Erving Goffman, Canadian sociologist; Franco Basaglia, Italian physician; Paulo Delgado, Brazilian professor, and politician. All of these authors defended the closure of psychiatric hospitals (on a similar theme to that used by the Queen of Wonderland: "Cut off her head"), as well as the implementation of a network of out-of-hospital services, based on the idea of dehospitalization and deinstitutionalization. It is evident that, unlike the Queen, the decapitation in mental health, which corresponded to the closure of psychiatric hospitals and, consequently, the implementation of a network of out-of-hospital services, presented a logical meaning, based on the idea of dehospitalization and deinstitutionalization. 
This was because, for these authors, psychiatric institutionalization, and hospital treatment implied restriction of freedom, which, in addition to repressive practices, did not promote care, but rather mortification and illness in the subject ${ }^{(1,5)}$.

The political and legal structure to combat dehospitalization and deinstitutionalization emerged after $2000^{(6)}$. It occurred more specifically in Brazil with Law $N^{\circ}$. 10.216/2001 and Ordinance $\mathrm{N}^{\circ}$. $3.088 / 2011$. The first one determined that psychiatric hospitalization should be the last resort for mental health care. The second established the Psychosocial Care Network (PCN) for people with mental suffering or disorder and in need to treat crack, alcohol, and other drugs within the Unified Health System (SUS) and excluded the psychiatric hospital from that network. Under the law, contrary to the late 1990s, the number of beds and psychiatric hospital services decreased throughout the country ${ }^{(6,7)}$.

Therefore, it is noticeable that the existential condition of psychiatric hospitals coexists with the dilemma comparable to Alice's, of increasing or decreasing in size. According to the Caterpillar, Alice's growth and decrease depends on the number of mushrooms she ate. The Caterpillar's symbolism was used in the literary work to express the metamorphosis as an inevitable condition occurring throughout life. Mushrooms show the mastery of life/history in their own hands. In the case of psychiatric hospitals, the fate of their existence is conditioned by the "many hands" (elements linked to the functioning of these institutions): politics, legislation, social representations, health care medicalization, and economic growth ${ }^{(5)}$.

To this day, psychiatric hospitals are still existing and are widely used as mental health services worldwide. In some countries, such as Brazil, there is an argument vindicating psychiatric hospitals' permanence in the Health Services Network. In November 2019, Technical Note $\mathrm{N}^{\circ} .11$ published the allegation that the closing of psychiatric beds in the last two decades was a misunderstanding caused, mainly, overcrowding of Emergency Services, with patients waiting for vacancies for psychiatric hospitalization. The Note defends the permanence of psychiatric hospitals, assures the inclusion of that service into the PCN, and allows the possibility to follow modern protocols and treatment standards in these services, such as electroshock ${ }^{(8)}$.

The historical context of the psychiatric institution presented in this study resembles the movement in circles that the characters (the Hare, the Mad Hatter, and the Dormouse) in Alice's story made around the tea table when time stopped running for the Hatter. Regarding the psychiatric hospital, the movement revolves around its maintenance as a place where care is offered.

\section{The worker in the psychiatric hospital: The Queen's soldiers and Alice's Cat}

The focus now is on the psychiatric hospital worker, as part of a complex history involving this institution. To initiate the proposed discussion, the following is an excerpt from Alice's work in Wonderland:

Alice, lost in the forest, finds a Cat and his intriguing smile. This one guides her to a path. And he warns her that this path will lead her to a place, where everyone, supposedly, is mad: "In this direction," said the Cat, turning his right paw, "there lives a Hatter. And in this direction," pointing with his left paw, "lives a March Hare. Visit which one you want: they are both crazy". "But I don't want to mess with crazy people," Alice observed. "Oh! It's inevitable," said the Cat, "we're all crazy around here. I am crazy. You're crazy. "How do you know I'm crazy?" said Alice. "It can only be," said the Cat, "otherwise you wouldn't have come here."'And how do you know you're crazy?" asked Alice. "To begin with," said the Cat, "a dog is not crazy. Do you admit that?"“I suppose so," said Alice. "Well," continued the Cat, "you know, a dog growls when it's mad and waggles its tail when it's happy. Now, I growl when I'm happy and wag my tail when I'm angry. So, I'm crazy" (2).

The Cat's assertion that everyone is crazy for being in a particular place (Wonderland) reminds us that we can also find that assertion in the real world. There is a social attribution that those who, in some way, are part of the psychiatric hospital context are crazy, including people working there, whether a psychiatrist, psychologist, nurse, guard, social worker, Nor even a teacher. It does not matter the profession. Based on scientific studies, if they are involved in this context, they carry the mental health job's stigma, which appears among those who work in psychiatric hospital services, possibly due to the negative burden of the history of these hospitals and the workers' understanding of madness ${ }^{(9)}$.

In the dialogue between the Cat and Alice, there is a categorical demonstration that madness can have different conceptions. In humanity's history, the notion of madness has been associated with various aspects: mystical, religious, organicist, until the present day, to the psychosocial line of thinking. In parallel with the assigned concept, forms of treatment were established, or rather, the labor practice in mental health services ${ }^{(1)}$.

At the time of Pinel and Esquirol, when there was no drug treatment (which appeared only in the 1950s), workers in psychiatric services, called "alienists," were considered the most efficient agents for the mental alienation cure. Through them, it was carried out a moral treatment, as an offer of the medical regime, deprivation of external influences, imposition of new habits, and a guarantee of safety to the insane and their families. Over time, many of the workers questioned this practice in psychiatric hospitals. Among them stands out the physician Franco Basaglia, who defended the idea of overcoming the asylum apparatus and improving working conditions ${ }^{(1,4)}$.

In this case, Basaglia and Alice have something in common. Instead of surrendering to the stigma and alienation environment, they questioned and fought against the attributed inconsistencies. Nevertheless, not all the characters in the world of psychiatry or Wonders were the same as Basaglia or Alice. Many submitted to the establishment. To illustrate this fact, we present another fragment of Alice's story:

At the entrance of the Queen's garden there was a large rose-tree: the roses born there were white, but three soldier gardeners, in a shape of playing cards, were busy painting them red. [...] "Would you tell me," said Alice timidly, "why are you painting those roses? Five and Seven said nothing but looked at Two. Two began in a low voice, "Why the fact is, you see, Miss, this here ought to have been a red rose-tree, and we put a white 
one in by mistake; and if the Queen finds out, we should all have our heads cut off, you know? So, you see, Miss, we are doing our best, before she comes, to..."(2).

The Queen's soldiers, symbolically represented as playing cards, act coerced out of fear of being beheaded. Not much different from what happens in the workplace environment today. In the case of psychiatric hospitals, studies reveal that workers in these services, often for fear of becoming unemployed or other similar situations, submit to unhealthy environmental conditions, lack of materials to carry out their duties, and precariousness of work (low wages; excessive workload; contractual informality) ${ }^{(9)}$.

As discussed earlier, psychiatric hospitals were marked by a complex history of confronting knowledge and rules. While some argue behind the "bricks and mortars," patients and workers of such services survive, having to adapt to countless versions. In Brazil, for example, between the 1970s and the 2000s, professionals treated people with a mental health condition using straitjackets and electroconvulsive therapy as a treatment strategy. Since 2001, with Law 10.216, a new labor practice has been declared for all mental health services, prohibiting the use of straitjacket and electroconvulsive therapy. In 2011, it was established a Psychosocial Care Network (PCN) and, although hospitals still offered care and use more humane and comprehensive techniques, such as art therapy, they were not considered members of this network. However, in 2019, the hospital was legally included in the PCNs, with the possibility of using electroconvulsive therapy in these services ${ }^{(4,6,8)}$.

The story described above reminds us of scenes from Alice's book: the Mad Tea party with circle movement of the table (already described earlier in this study) and Alice lost among many paths, which went in various directions in the forest. In this last scene, Alice sees the Cat sitting on a tree, with his enigmatic smile. She then takes the opportunity to ask him: "Could you please tell me which path I should take to get out of here?" "It depends a lot on where you want to go," replied the Cat. "I don't really care where to go," said Alice. "So, it doesn't matter which way you take it," said the Cat ${ }^{(2)}$.

In the history of psychiatric hospitals, there are also many directions. There may be many confusing "Alices," or they are just following the course of what is determined about their labor practice. Studies reveal that dealing with subordination, contradictory orders, and multiple commands can generate psychological overload and illness in workers ${ }^{(5)}$. Among the overloads reported by psychiatric hospital workers in recent times, the cognitive demand stands out, for not being able to offer better quality care to their patients, even though they often feel like a "playing card in a game," which is not always fair for all players, including them ${ }^{(3,9)}$. And speaking of the game as a representation of the dynamics of everyday life, the following part of the chapter "The Queen's croquet ground" from Wonderland is presented:

Croquet is quite difficult to play, since balls and clubs are live animals, manipulated by the Queen and the King. The Queen invites Alice to play a match. She accepts. But the match is interrupted by the appearance of an enigmatic smile of the Cat in the air: "How are you getting on?" asked the Cat, as soon as there was mouth for him to speak. [...] "I don't think they play at all fairly," Alice began in a complaining tone, "and they all quarrel so dreadfully one can't hear one's own voice... and they don't seem to have any rules in particular; at least, if there are, nobody attends to them - and you've no idea how confusing it is all things being alive! ${ }^{(2)}$

If the match is complicated and confusing in Wonderland, let alone in a psychiatric hospital, where work alone is not a relatively easy task. Those who work in these places deal with unforeseen events, such as the risk of being attacked due to the clinical nature of the patients, unhealthy environments, scarcity of resources, stigmatization, the plurality of rules, the existence of informal employment contracts, and the threat of becoming unemployed if the institution ceases to exist. Nevertheless, studies have recently identified that some professionals are somehow satisfied with working in these places ${ }^{(9)}$.

So, in light of the analogy between the Cat's smile in Alice's story and the satisfaction of the psychiatric hospital workers, one may ask: What is behind that smile? How to smile in such a delusional world? Is it an expression of satisfaction, innocence, fear, or irony? When it comes to job satisfaction, research shows that workers are more satisfied with interpersonal relationships in the workplace and dissatisfied with organizational aspects (salaries, benefits, little control over the work, shortage of professionals, long shifts, among others). Dealing with psychiatric patients appears to be a relevant factor in the work environment, although there is a risk of being attacked. For the employees, many of the patients are victims of their pathology and social abandonment and, therefore, need care ${ }^{(3,9)}$.

Although job satisfaction is relevant, it is necessary to know the hidden pitfalls in jobs in unsafe environments. Workplaces with this profile inhibit the subjects from being critical and reflective about their conditions. Moreover, the logic of knowledge and power, existing in the history of psychiatric hospitals ${ }^{(3)}$, may intimidate the worker from exposing his opinion, which can happen due to the fear of ending up receiving responses similar to those that Alice got from some characters in Wonderland: "You have as much right (to think) as pigs have to fly [...]" (Duchess); "You are really quite ignorant! (Mock Turtle, who claimed to have better education); "You should be ashamed to ask such a stupid question"(2).

\section{FINAL CONSIDERATIONS}

This study intended to present a reflection on the labor practice historically developed in psychiatric hospitals. It has been highlighted that the concept attributed to madness over time powerfully shapes workers' behavior and attitudes in these services. Evidently, it happens governed by the laws, rules, knowledge, and powers instituted beyond the walls of institutions.

Apparently, the psychiatric hospital's trajectory goes around in a circular movement, whose centrality and existence in the context of Mental Health Care and the practices developed in it perpetuates in the process of coming and going. In this sense, the worker may feel confused about his or her role in these services.

Thinking about mental health is not limited to reflect exclusively on the barbarities experienced by patients in asylums. On the 
one hand, the intention here is not to minimize these individuals' situation, who, admittedly, were the greatest victims in all this history. However, on the other hand, it is also necessary to look again at those who are part of this not "Wonderful" world, in which reality, much more due to the rational conditions of man, puts them in a game of "beheading" their labor rights.

It is understood, therefore, that it is essential that new Alices fight for themselves and the collectivity and that there is an expansion of the debate on work in the psychiatric hospital nowadays, through strategies that enable workers to reframe their space as a subject, not being reduced only to a working tool.

Finally, it is necessary to be alert to the consequences possibly generated by the publication of the Technical Note $N^{\circ} 11 / 2019$, considering that it contradicts both the historical landmark of the Anti-asylum Fight Movement and the principles of the Psychiatric Reform.

\section{REFERENCES}

1. Amarante P. Saúde Mental Atenção Psicossocial. Rio de Janeiro: Fiocruz; 2007. 120 p.

2. Carrol L. Aventuras de Alice no país das maravilhas \& Alice através do espelho: edição comentada. Rio de Janeiro: Zahar; 2013.416 p.

3. Paula GS, Oliveira EB, Silva AV, Souza SRC, Fabri JMG, Guerra OA. Work-related violence in psychiatry in the perception of nursing workers. SMAD, Saúde Mental Alcool Drog. 2017;13(2):86-92. https://doi.org/10.11606/issn.1806-6976.v13i2p86-92

4. Del'olmo FS, Cervi TMD. Mental suffering and human person dignity: the challenges of psychiatric reform in Brazil. Seqüência. 2017;77:197220. https://doi.org/10.5007/2177-7055.2017v38n77p197

5. Zgiet J. Alienated work and mental alienation: the psychiatric reform in capitalism. Tempus (Brasília). 2018;11(3):130-43. https://doi. org/10.18569/tem.pus.v11i3.2433

6. Presidência da República (BR). Lei n 10.216, de 6 de abril de 2001. Dispõe sobre a proteção e os direitos das pessoas portadoras de transtornos mentais e redireciona o modelo assistencial em saúde mental[Internet]. Diário Oficial da União. 2001 apr 6. [cited 2019 Dec 22] Available from: http://www.planalto.gov.br/ccivil_03/LEIS/LEIS_2001/L10216.htm\#: :text=LEI\%20No\%2010.216\%2C\%20DE,Art

7. Ministério da Saúde (BR). Portaria n 3.088, de 23 de dezembro de 2011. Institui a Rede de Atenção Psicossocial para pessoas com sofrimento ou transtorno mental e com necessidades decorrentes do uso de crack, álcool e outras drogas, no âmbito do Sistema Único de Saúde (SUS) [Internet]. Brasília: Ministério da Saúde; 2011 [cited 2020 Feb 01]. Available from: http://bvsms.saude.gov.br/bvs/saudelegis/ gm/2011/prt3088_23_12_2011_rep.html

8. Ministério da Saúde (BR) Nota Técnica n 11, de 04 de fevereiro de 2019. Assunto: Esclarecimentos sobre as mudanças na Política Nacional de Saúde Mental e nas Diretrizes da Política Nacional sobre Drogas [Internet]. Brasília: Ministério da Saúde. 2019 [cited 2020 Feb 13]. Available from: http://pbpd.org.br/wp-content/uploads/2019/02/0656ad6e.pdf

9. Telles LL, Jardim SR, Rotenberg L. Call me for a conversation and I will enjoy it: analysis of a clinical-institutional experience with the nursing staff of a psychiatric hospital. Ciênc Saúde Colet. 2020;25(1):181-190. https://doi.org/10.1590/1413-81232020251.28882019 